\title{
Discovery of the Skull of a Grizzly Bear in Labrador
}

\section{ARTHUR SPIESS and STEVEN COX ${ }^{1}$}

\begin{abstract}
The skull of a small, young adult grizzly bear was discovered in the course of archæological excavation of an early historic Eskimo house in northern Labrador. This discovery confirms the rumoured presence of Ursus arctos in Labrador in the eighteenth and nineteenth centuries. It is suggested that the Labrador grizzly represents an eastward extension of the barren-ground grizzly population across the mouth of Hudson Bay.
\end{abstract}

RÉSUMÉ. Découverte d'un crâne de grizzli au Labrador. Le crâne d'un petit et jeune grizzli adulte fut découvert au cours de fouilles archéologiques destinées à mettre à jour une des premières maisons historiques esquimaudes dans le nord du Labrador. Cette découverte confirme la rumeur de la présence de l'Ursus arctos au Labrador au cours des dix-huitième et dix-neuvième siècles. L'auteur suggège que le grizzli du Labrador représente une extension vers l'est de la population grizzli de l'autre côté de la bouche de la mer d'Hudson.

РЕЗЮМЕ. Находка черепа медведя-гризли на Лабрадоре. При археологических раскопках в северной части Лабрадора возле әскимосского дома раннего исторического периода был обнаружен череп неболышого молодого медведягривли. Эта находка подтверждает догадки о присутствии Ursus arctos на Лабрадоре в 18-19 вв. Делается предположение, что лабрадорский гриали является представителем двитавшейся на восток через горло Гудзонова залива популяции медведя-гризли.

THE SPECIMEN

The well-preserved skull of a small grizzly bear (Ursus arctos L.) was discovered during the course of archaeological excavation in an eighteenth century Eskimo midden at Okak Bay, Labrador $\left(57^{\circ} 34^{\prime} 30^{\prime \prime} \mathrm{N}, 61^{\circ} 59^{\prime} \mathrm{W}\right)$ by Steven Cox during the summer of 1975 . This skull represents the first definite evidence of the existence of the species east of Hudson Bay during the Holocene, and provides confirmation of the long-standing rumours that a Labrador-Ungava barren-ground brown bear did exist.

The skull was discovered during test excavations of a Labrador Eskimo sod winter house on the north side of Okak Island. The house lies within a site containing 49 winter houses, some of which are known from historical sources to have been occupied by people who moved to the Moravian Mission settlement in Okak Harbour at the end of the eighteenth, or beginning of the nineteenth, century. The skull was found in a one-metre test square in the midden at the end of the entrance passage to the house. It was associated with artefacts of the contact period which serve to date the house to the latter half of the eighteenth century.

The Okak specimen consists of a nearly complete cranium with right and left fourth premolars, and first and second molars, intact. The rest of the teeth have

${ }^{1}$ Department of Anthropology, Harvard University, Cambridge, Mass. 02138, U.S.A. 
been lost, as have the zygomatic bones. The occipital condyles and the margin of the foramen magnum have been broken away. There is some weathering damage to the posterior basicranium and, particularly on the frontal and parietal bones, the outer cortical bone has begun to weather. (See Figs. 1 and 2.) The skull, which is the property of the Province of Newfoundland, is in the collection of the Newfoundland Museum, St. John's.

Taxonomic differentiation from Ursus Thalarctos maritimus (polar bear) and Ursus Euarctos americanus (black bear), both of which are known to exist in the Okak area, is based on the well-preserved teeth. In the Okak skull, and Ursus arctos in general, alveolar $\mathbf{M}^{\mathbf{1}}-\mathbf{M}^{\mathbf{2}}$ length is greater than palatal width, and the heel of $\mathrm{M}^{2}$ is not drastically reduced buccally. The maximum width of $\mathrm{M}^{2}$ is very close to the anterior margin of the tooth, and the deuterocone on $\mathbf{P}^{4}$ is well developed. (See Spiess 1976 for a more detailed description of the specimen.)

According to Rausch's (1961) age classification of Ursus spp., the Okak skull can be put in class 9 , in view of the moderate wear on the molars and an obliterated basioccipital-basisphenoid suture. Obliteration of this suture indicates that the skull had stopped increasing in length; however, the Okak grizzly was small. Its
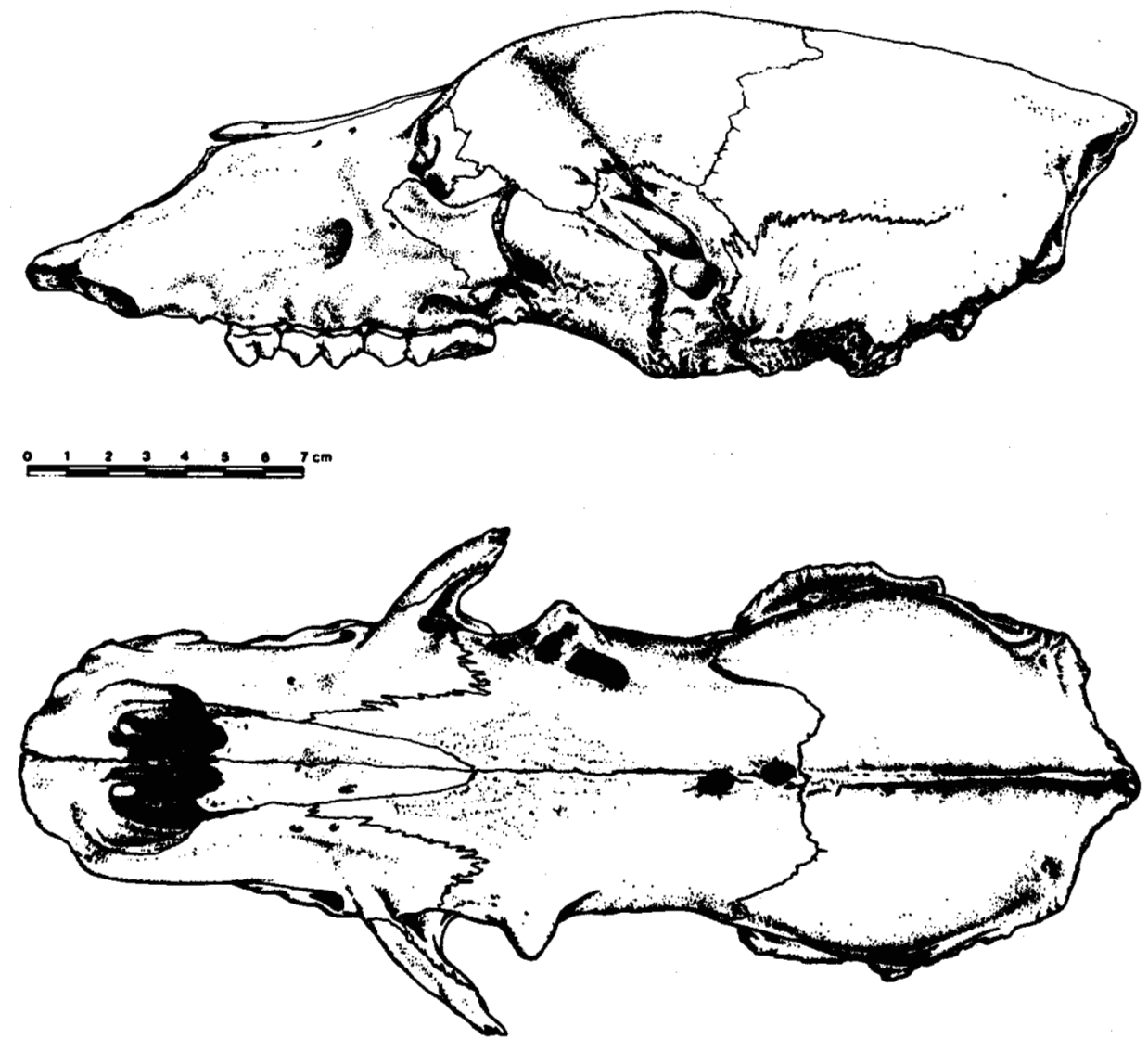

FIG. 1. Dorsal and lateral views of Okak skull. 


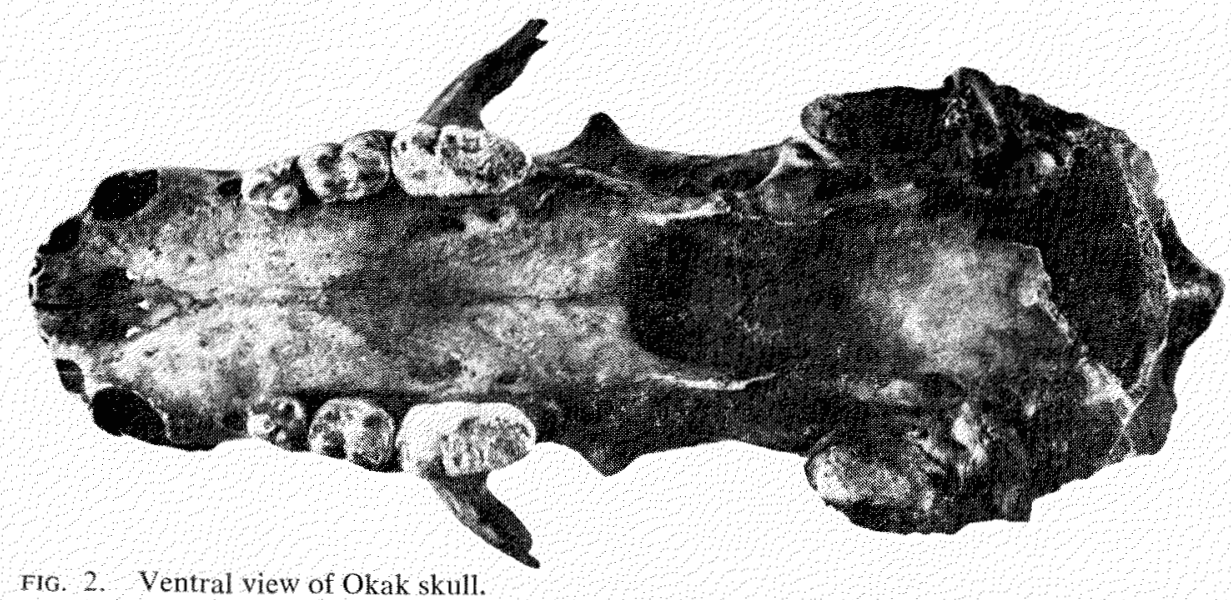

condylobasal length (Rausch 1963) was between 265 and $270 \mathrm{~mm}$; a closer estimate is precluded by the damage to the occipital area. For comparison, condylobasal lengths for adult North American female grizzlies - seven taken from Merriam (1918) and five measured in the collection of the Harvard Museum of Comparative Zoology - gave a mean of $297 \mathrm{~mm}$ and two-standard-deviation range of $263-331 \mathrm{~mm}$.

The skull of the Okak grizzly is full-grown (Rausch's age-class 9) and on the small side for North American females. Its condylobasal length is $30-35 \mathrm{~mm}$ below the range for any of Rausch's (1963) North American populations of males, and as it has a low sagittal crest confined to the back of the skull found in the skull of females and immature males it is thus believed by the present authors to be that of a female.

\section{RUMOURED EXISTENCE OF GRIZZLY BEARS IN LABRADOR}

The existence of the grizzly bear in Labrador-Ungava has been regarded by most mammalogists as unsubstantiated. Allen (1942) states that "the persistent reports of a grizzly bear existing in the barrens of northern Labrador have from time to time been investigated as far as such tales may, but no real evidence that such an animal is found there has been elicited. Even though the tale is true that a skin of a grizzly had once been brought in, this might have been traded from still further west."

Peterson (1966) is of a similar opinion: ". . . there have been persistent rumors and reports that an eastern form of grizzly bear, Ursus horribilis . ... once lived in the Ungava region of Quebec and persisted until about 1900. Unfortunately the evidence is conflicting. Reports of light-coloured bears in northern Quebec agree in description with the coloration of a grizzly bear, yet there is a strong possibility that the animals described were merely a brown colour-phase of the black-bear."

Banfield (1964), on the basis of negative evidence from aerial surveys made wholly or in part as a search for the Labrador-Ungava grizzly in 1953, 1954 and 
1956, states that "hearsay accounts of grizzlies have misled scientists more often than not, perhaps most in the case of the rumoured presence of the bears in the Ungava peninsula of northern Quebec and Labrador ...."

In view of the apparent rarity of the Labrador-Ungava grizzly, scepticism has been justified. Moreover, the negative data collected by Banfield should be taken to mean that grizzlies were probably absent from Labrador-Ungava in the nineteen fifties.

Previously, the most substantial bases for the rumours that grizzly bears existed in Labrador were trading records of rare pelts. Stirling (1884) quotes from a report of John McLean, a trader of the Hudson's Bay Company, who was stationed for some time at Cape Hope's Advance at the northwestern corner of Ungava Bay: "To enumerate the varieties of animals here is an easy task. The extremely barren nature of the country and the severity of climate prove so unfavorable to the animal kingdom that only a few of the most hardy species are to be found, viz., black, brown, grizzly, and polar bears. When we consider the great extent of country that intervenes between Ungava and the plains of the Far West, it seems quite inexplicable that the grizzly should be found in so isolated a situation and none in the intermediate country. The fact of their being here, however, does not admit of a doubt, for I have traded and sent to England several of these skins from the region of Ungava..."

Elton (1954) reviews fur-trade reports of grey, grizzly and brown bear skins from Labrador-Ungava, concluding that the bear was known from the tundra country at the northern tip of Labrador-Ungava, including the Torngat mountain area, and possibly the coastal tundra strip as far south as Nain $\left(56^{\circ} 30^{\prime} \mathrm{N}\right)$. Extant fur returns quoted by Elton include four "grey" bear skins from the Ungava District of the Hudson's Bay Company in 1838-39, and sixteen grey, grizzly or brown bear skins brought to the Moravian Mission settlements on the north Labrador coast between 1835 and 1863 . One grizzly and one brown bear skin respectively were traded for by the Moravians (station unspecified) in 1913-14 and 1925-26.

The last sighting of a large brown bear on the Labrador-Ungava barrens was made by the pilot and the navigator of a Royal Canadian Air Force flight in 1948 about $160 \mathrm{~km}$ northwest of Fort Chimo (Elton 1954 p. 349).

If both Elton's and McLean's statements are accepted, then Ursus arctos inhabited both the tundra areas of the Ungava peninsula and the northern tip of Labrador-Quebec east of Ungava Bay for at least some of the time span between 1771, when the Moravian Mission arrived in northern Labrador and began to keep records, and the nineteen fifties, when Banfield failed to find them. If the fur trade records are any indication, the Labrador grizzly population had declined significantly by 1900 .

\section{POSSIBLE POPULATION RELATIONSHIPS}

Peterson (1965) reported the finding of the skull of a grizzly bear from the late Pleistocene at Lake Simcoe, Ontario, which was radiocarbon dated at 11,700 \pm 250 years B.P. Thus, there are two possible historical views of the now-con- 
firmed Labrador-Ungava grizzly population: a relict group of descendants of late-Pleistocene eastern Canadian grizzlies, or a population related to Holocene grizzlies of the barren grounds west of Hudson Bay. Bryson et al. (1969) have detailed the northward retreat of the Laurentide Ice Sheet, at the edge of which the Lake Simcoe grizzly lived. If the eastern Canadian grizzly population followed the ice in its retreat northwards, it would have been in northern Labrador-Ungava by 6000 B.P. On the other hand, Banfield (1964) cites a rapid territorial expansion of the barren-ground grizzly population west of Hudson Bay in the nineteen forties and fifties, with the observation of grizzlies "on the ice" off Southampton Island in the mouth of Hudson Bay in 1948 and 1950. A grizzly population on Southampton Island would be but $150 \mathrm{~km}$ from the northwestern corner of the Ungava peninsula.

Rausch (1963) places all mainland North American Ursus arctos in one subspecies, U. a. horribilis. Thus, in trying to decide ancestral affinity for the Okak specimen, one is dealing with differences below the subspecies level in a species characterized by very considerable individual variation and in a situation where two of the three populations involved (Okak and Lake Simcoe) are represented at present by single specimens. It is clearly impossible to be definitive.

Rausch (1963) has produced interesting evidence that condylobasal length of skull declines with distance along the Arctic coast of Alaska and Canada from west to east. The smallest mean condylobasal length for the males of any of the 26 populations sampled $(324 \mathrm{~mm})$ was that for the Coronation Gulf area, the easternmost investigated. Continuation or intensification of whatever selection pressures, gene flow phenomena, or ecological conditions are responsible for the small populations along the Arctic coast would produce a smaller population in Labrador-Ungava.

Considering Banfield's evidence of significant territorial expansion of the grizzly population just west of Hudson Bay in the nineteen forties and fifties despite the presence of modern, rifle-armed populations of Eskimo hunters, the extinction of the Labrador grizzly in the nineteenth or twentieth century cannot reasonably be ascribed to fur-trade induced overhunting, unless the Labrador grizzly population was also endangered by small numbers and low reproductive rates such as would indicate generally marginal conditions for survival. On purely inductive grounds, then, long-term survival of an isolated late-Pleistocene population in Labrador-Ungava seems unlikely. It is much more likely that the LabradorUngava bears known in the eighteenth, nineteenth and early twentieth centuries constituted a marginal population established east of Hudson Bay in the way Banfield has so adequately documented, i.e. territorial and, theoretically, population expansion. The fact that the territorial expansion of barren-ground grizzly bears has occurred into the territory of a modern hunting population indicates that Labrador-Ungava may even be repopulated by these bears in the future.

\section{THE GRIZZLY BEAR AND THE LABRADOR ESKIMO ECONOMY}

Bears generally played a minor part in the Labrador Eskimo economy, with the polar bear and the black bear still both being involved today. Of 1400 bones 
identified from Okak Labrador Eskimo sites of the eighteenth and nineteenth centuries, only six $(0.4 \%)$ were ursid (bear). Two large ursid ribs and a phalanx came from the same test pit as the skull. Another Eskimo winter house yielded a large ursid ulna and a metatarsal fragment. The fur records of the Moravian mission settlements compiled by Elton (1954) suggest an average take of one grizzly bear every two years by hunters from Nain to Hebron for the period from 1835 until 1865.

The most likely periods of human-grizzly encounter would have been during the trips made inland by the Labrador Eskimo in the fall and spring to hunt caribou. During such trips the Eskimo travelled up to $300 \mathrm{~km}$ inland, rarely crossing the George River, and generally remained in the interior for several weeks (Elton 1942 p. 374; Taylor 1969, 1974). It is also possible, however, that an occasional grizzly penetrated to the coast, particularly during May when caribou drop their calves just southwest of Saglek Bay, or during the early summer when there are numerous fish (char, salmon, trout) available in all the bays.

Stefansson (1914 p. 56) reported that grizzlies were as avidly hunted as polar bears whenever sighted by the Eskimos west of Hudson Bay:

... most mainland tribes kill (a brown bear) now and then, especially the Akulliakattagmiut [at the western end of Coronation Gulf - author's note]. If found still in the stupor of hibernation they are easily despatched, but if awake (any time after the middle of April, or even sooner) they are more difficult game than polar bears. One or two good dogs will generally keep a polar bear at bay; it is seldom dogs can hold a barren-ground bear. At close quarters, too, they are more dangerous than white bears both to man and dogs, and many a man bears the mark of their claws! They are however attacked single handed, by hunters armed with only bow and knife. We were told that the hunter sometimes pays for his venturesomeness with his life.

The Naskapie Indians, too, spoke of the Labrador grizzly "with dread" in 1900 (Elton 1954 pp. 348-9).

Although the Ungava-Labrador grizzly did not make significant contributions to the Labrador Eskimo and Indian larder, it certainly made an impression on their psyche, giving rise to the rumours and legends told to white settlers, traders and missionaries which eventually reached the mammalogist's desk. Some credence must now be given to their tales.

\section{ACKNOWLEDGEMENTS}

The archæological work which recovered the Okak skull was supported by U.S. National Science Foundation Grant \#GS-42896 to Cox. Spiess received Grant \#150 from the Arctic Institute of North America for a survey of the ecology of Okak Bay during the 1974 field season and analysis of recovered faunal remains in the laboratory. 


\section{REFERENCES}

ALLEN, G. 1942. Extinct and Vanishing Mammals of the Western Hemisphere. Lancaster, Pa.: American Committee for International Wildlife Preservation.

BANFIELD, A. W. F. 1964. Grizzly territory. Natural History, 73: 22-27

BRYSON, R., WENDLAND, W., IVES, J. and ANDREWS, J. 1969. Radiocarbon isochrones on the disintegration of the Laurentide Ice Sheet. Arctic and Alpine Research, 1: 1-14.

eltoN, c. 1942. Voles, Mice and Lemmings. Oxford: Clarendon Press.

1954. Further evidence about the barren-ground grizzly bear in northeast Labrador and Quebec. Journal of Mammalogy, 35: 345-57.

MERRIAM, C. 1918. Review of the grizzly and big brown bears of North America. Washington, D.C.: U.S. Government Printing Office (North American Fauna no. 41).

PETERSON, R. 1965. A well-preserved grizzly-bear skull recovered from a late-glacial deposit near Lake Simcoe, Ontario. Nature, 208: 1233-4.

1966. The Mammals of Eastern Canada. Toronto: Oxford University Press.

RAUSCH, R, 1961. Notes on the black bear, Ursus americanus Pallas, in Alaska, with particular reference to dentition and growth. Zeitschrift für Säugetierkunde, 26: 77-107.

SPIEss, A. 1976. Labrador grizzly (Ursus arctos L.): first skeletal evidence. Journal of Mammalogy, 57 (in press).

STEFANSSON, v. 1914. The Stefansson-Anderson Arctic Expedition of the American Museum: Preliminary Ethnological Report. New York: American Museum of Natural History (Anthropological Paper no. 14).

STIRLING, E. 1884. The grizzly bear in Labrador. Forest and Stream, 22: 324.

TAYLOR, J. G. 1969. William Turner's journeys to the caribou country with the Labrador Eskimos in 1780. Ethnohistory, 16: 141-64.

1974. Labrador Eskimo Settlements of the Early Contact Period. Ottawa: National Museum of Man (Publications in Ethnology no. 9). 